\title{
Study on Architectural Characteristics of New Art Style in Harbin
}

\author{
Xin Ni \\ School of Design and Art \\ Harbin University of Commerce \\ Harbin, China
}

\begin{abstract}
On June 9, 1898, the Middle East Railway was put into construction in Harbin, and Harbin became the northern largest city in China. Since her rise, the city has always enjoyed the reputations of "Oriental Moscow" and "Little Paris in the Orient". Her beauty owed to her beautiful architectures of "new art" style. The earliest architectures of "new art" style were completely transplanted from Russia. Harbin's architectures of "new art" style have the characteristics of subjectivity and popularity, regional differences and regional adaptability.
\end{abstract}

\section{Keywords-new art; characteristics; Harbin; architecture}

\section{INTRODUCTION}

On June 9, 1898, the Middle East Railway was put into construction in Harbin, and Harbin became the northernmost large city in China. Since her rise, the city has always enjoyed the reputations of "Oriental Moscow" and "Little Paris in the Orient". Her beauty owes to her beautiful architectures of "new art" style. From the view of an isolated incident, it is just a coincidence that the new art movement, born in the western aesthetic system, overcame various obstacles and spread into the ancient and magical oriental country. But from the historical background, the unexpected coming of new art movement is the inevitable product of European architectural style in the era of "Railway Mania" spreading into the Orient, which makes Harbin's architectures of "new art" style with a series of era intercommunity and regional differences.

\section{THE CHARACTERISTIC OF ERA INTERCOMMUNITY IN HARBIN's ARCHITECTURES OF “NEW ART” STYLE}

"New Art" Movement was spread through France, Belgium, Germany, Austria, Poland and Russia and other countries to the Far East. Harbin was the last stop in this direction. Before construction, Harbin was almost a piece of virgin land. The earliest architectures of "new art" style were completed transplanted from Russia, from design to construction, which gives the architectures of "new art" style with typicality and purity.

Of course, strictly speaking, the new art movement itself cannot be summed up as a certain style. Its formal language is rich and varied. But we can also call it a kind of style, because, from its connotation, the art practice in the new art movement essentially is a continuation and improvement of the

This paper is a study on Inheritance and Development of Harbin's Architectures of "New Art" Style, belonging to Heilongiang Art Science Planning Project (C011).. theoretical system of Ruskin "Arts and Crafts" Movement. Its theoretical premise is uniform. The architectural theory of the new art movement has an affinity for the people, for it has never served the kings or the Pope. Its service objects are urban construction, public life and elite residence. From this point, it already has the basis for the evolution of modern architectural form.

The architecture in the "new art movement" is an exploration on architectural aesthetics in the architecture and art circles in the specific mechanical industry era and a reaction to old one-sided mannered eclecticism existing in quite a long historical period. In the form language, the "new art movement" gave up to inherit all old styles. It turned to reexamining the nature, learning from the nature and pursuing new forms of aesthetics. The large application of non-plane, curve and organic forms and the obvious weakening of traditional architectural decoration elements can be regarded as the general characteristics of this style, which is also uniform. These characteristics are obviously reflected by Harbin's architectures of new art style. It is the end stop and an important stop of the new art movement around the world.

Compared with the intercommunity, Harbin's architectures of "new art" style have their own unique characteristics, and they are very valuable.

\section{THE OWN CHARACTERISTICS OF HARBIN'S ARCHITECTURES OF “NEW ART” STYLE}

\section{A. Harbin's Architectures of "New Art" Style Have the Characteristics of Subjectivity and Popularity}

The western new art movement had to get rid of the history burdens deposited for thousands of years from new classicism, eclecticism, romanticism and other architectural forms. However, Harbin has no historical burden. From the beginning of her construction, the "new art" architectural style has always occupied a dominant position in Harbin. It is the most mainstream form language in urban construction. The "new art" style here wantonly expanded territory. The new art style has implanted the first seed in hearts of people in this city. In order to realize Tsar's "Yellow Russia" dream of aggression, from 1899 Russia officially constructed Harbin, as "railway subsidiary", in a colonial style. In this piece of virgin land, almost everything should be started from scratch. The city planning, with Qinjiagang (Nangang District) as center, was 
started. In 1902 Russia's Finance Minister, Victor de Witt, further established the political and economic status of Harbin as Russia's strategic tentacle in the central region of Manchuria. In 1904, the original Harbin Railway Station (ruined), the important transport hub of the Middle East Railway and the representative architecture of "new art" style, was completed. In the short few years, a number of outstanding "new art" styled architectures were sprung up. The original Xiangfang Gongyuan Restaurant (ruined), the mansion of former director of the Middle East Railway Administration (ruined), the original mansion of the Middle East Railway Committee (on Hongjun Street), the original Harbin Business Club (on Shangyou Street), the original Moscow Bazaar (on Hongjun Street), Modern Hotel (on Central Avenue), the original building of the Middle East Railway Administration (on Xida Street), etc. are all excellent works completed in this period. The prevailing of new art style in Harbin and its irreplaceable status guarantee its long and rapid development.

\section{B. Harbin's Architectures of "New Art" Style Have Regional Differences and Regional Adaptability}

It almost completely abandoned all elements of all historical forms, so the development of new art movement has obvious regional differences in this place. Under influence of the near general trend of thought, France, Spain, Belgium, Germany, Austria and other places have developed different "new art" results. Even individual countries have differences in the formulation of "new art". In Germany, for example, people call the new art movement as "youth style", while in Austria people call it "Vienna Secession". Harbin's "new art" styled architecture also has regional characteristics. In order to meet the need of the construction and development of Harbin, Harbin's public architectures of "new art" style is more simple than those in Europe. It got rid of complex and unnecessary decoration, so as to accelerate construction and make it more practical. In order to meet the urgent residence demand, part of private missions in Harbin used standardized batched construction form to shorten design time and design cost. In the aesthetic form, due to its simplification, the symbolic features of Harbin's architectures of new art style become more apparent, and even surpass the Russia and Western Europe. From this perspective, it has more potential to develop to modernization. From the vertical perspective of language, it consciously broke the level line and used the vertical components, directly access to the sky, forming a jumping contour approach, which makes building more solemn. In fact it has assumed the political task that the classical architectural language should bear with a new language form. The original Middle East Railway Administration building is the best example. Due to limitations of production conditions, the building didn't use colorful glass mosaic that Russia's new art style and many other architectural schools have always used in the new art movement. The color of the entire building is relatively uniform, which makes the entire street come close to modern style. Due to the changes of the international situation, Harbin's "new art" style in the middle and late period blended together with the eclecticism. They are all the embodiment of the localization of "new art" style in Harbin.

\section{The Development of Harbin's "New Art" Styled Architecture Has the Characteristics of Purity, Continuity and Extension}

With the construction of the Middle East Railway, a group of outstanding Russian architects came to China. If we browse these architects' resume, we will find that many of them were out of the campus at the peak of European's "new art" movement. At that time, Tsarist Russia has always actively learned from Western Europe. So, it is not difficult to understand what they've learnt at school. They came to Harbin with the determination to practice "new art" thought. Many of them devoted all their life to this city. They even were littleknown by Russian. For example, Visan (1873 1937), designer of Harbin Modern Hotel, has designed more than thirty buildings for this city. And then he forever rested in this place. Because of the remoteness of Harbin, their designs are hardly subject to any other mainstream architectural trend. According to the information transmission speed, their knowledge system was bound to never get complete and quick update, but only to rely on knowledge learnt at school and the accumulation of experience in the process of working in Harbin. This objectively makes Harbin's "new art" practice receive in-depth thinking and comprehensive, considerable development.

\section{Harbin's "New Art" Styled Architecture Has the \\ Characteristics of Openness, Flexibility and Inclusiveness, Full of Creativity}

Harbin's urban construction is open, and it has not been bound by a certain culture. This made it possible to quickly accept new things, and embrace everything useful. Its production, development blending and demise are naturally occurring. Analyzing from this big historical environment, Harbin's "new art" styled architecture has four historical development periods.

In the early days, Harbin fully transplanted Russia's "new art" architectural style with strong regional characteristics. This period of architecture is more idealistic and romantic. They were the products of the first great development of Harbin, which laid the leading position of Harbin's "new art" styled architecture.

Since 1905 after the Russo Japanese War, Japan, France, Germany, America, Europe, Britain and other countries have set up consulates in Harbin one after another. Harbin's "new art" architecture style developed into a stage of transition, and began to compromise with the new architectural form. This compromise does not refer to the traditional eclecticism. It can be seen as an improvement of diversified visual elements based on the "new art" style. The original Middle East Railway Supervision Office (on Xida Street), the original South Manchuria Railway "Japanese \& Manchuria Chamber of Commerce" (on Gogol Street), the original Harbin Branch of Japanese \& Korean Bank (on Diduan Street), the original Chistiakov's Tea Stall (on Hongjun Street) and other buildings were built in this period. At the same time, the architectural ideas of the first generation of architects in Harbin were also updated during this period, and they began to absorb the elements of "new art" style. For example, the contemporaneous Harbin Modern Hotel and the original 
building of Daoli Qiulin Company (on Central Avenue) were designed with more classical charm.

The third stage was after the outbreak of the October revolutionary war in Russia in 1917. A large number of Russian refugees flocked in Harbin. Among them there were many Russian architects of the second generation grown up after 1920. After this, China finally got the jurisdiction of the city. In order to seize the vacancy left by the Russian revolution, Japan, Britain, America, France, Germany, Italy and other countries continued to increase investment, and Denmark, Holland, Portugal, Italy, Belgium and other countries set up consulates in Harbin one after another. Diversified economic growth finally made Harbin's architecture completely compromised. But after all, the "new art" style was the most deeply rooted form in the urban construction of Harbin. Its language in this period was mainly reflected by parts of eclectic architecture. In addition, the technology and art used in local components of batched buildings were based on the "new art" style. The eclectic architecture design in Harbin is almost impossible to avoid elements of new art style, so the "new art" architectural language still has a broad market.

The last stage was after 1932, and Japan fully controlled Harbin. Old architectural forms in Harbin began to be gradually replaced by Japanese modern architecture. The new art movement in Harbin was coming to the end, and it developed toward flat symbolization. But at that time, some individual architectural components and symbols still used the language form of the new art style. The awning in front of Harbin Longmen Building is the relic of late "new art" style. Circles and bar symbols on No. $73 \sim 79$ Residence, Jingwei Street are also concrete embodiment of symbolization of late "new art" style.

From the above development course, we can come to the conclusion that Harbin's new art style has no dogma, and it is always open and inclusive and flexible. It also actively absorbs elements of other architectural forms, so it has considerable creativity different from simple eclecticism.

\section{E. The Development of Harbin's "New Art” Style Has Characteristics of Integrity, Health and Accumulation}

From the above development process we know that the evolution of Harbin's "new art" style lasted to the 1830s. The new art movement in Europe has only developed for ten years and then was aborted because of the war. However, the new art movement in Harbin has gone through several complete stages, and it was never polluted by affection and impairment occurring in the late "new art" movement in Europe. It was never pressed by any forces until it ended, which guarantees Harbin's new art movement with a healthy development course and distinctive artistic achievements, and provides us much valuable design experience and mature design cases. And they become today's architectural heritage.

\section{CONCLUSION}

After the gradual disappearance of the "new art" movement in Harbin, today, it has spanned the development stage of the whole modernism style. After such a long history, we can filter out the legacy of the new art movement through the absence of modernist architecture from the perspective of a new Harbin man. Of course, we can see clues of functionalism in the results of the "new art movement", even in some individual architects' work. For example, we can see deconstruction and recombination of traditional elements from Gaudy's work. Harbin's architecture of "new art" style has developed such many new characteristics compared with "new art" styled architecture in Europe. But as a whole, architects' exploration still stays on old classic thinking system. To us in this age they are historical and old. The purpose of the study is not to simply maintain a dead architectural style, but to reconstruct and recombine old architectural style in depth from the angle of new era and make it serve us, so that we can inherit excellent traditional elements to serve the modern building system. Seen Harbin's new art styled architecture from this angle, we will find that compared with the "new art" movement in the era of "Railway Mania" and the era of "Industrial Production Craze" followed by, the curve and natural forms are more suitable for our era of "Technology Craze" with network and digital design as the representative. Compared with the traditional handicraft technology, parametric design has made the realization of curve and natural pursuit extremely simple. From this perspective, Harbin's beautiful architectural forms of "new art" style is such a treasure. More beautiful and more ecological characteristic city is coming to us.

\section{REFERENCES}

[1] Wang Shouzhi. History of Modern Architecture. China's Architecture Industry Press, 1999

[2] Liu Yanjie. Semiotic Interpretation of "New Art" Styled Architectures in Harbin. Harbin Institute of Technology, 2008.

[3] Planning Bureau of Harbin. Solidified Movement: An Overview of Preserved Architectures in Harbin. China's Architecture Industry Press, 2005.

[4] Liu Songfu. Outpost of Western Modern Architecture into China: Characteristics and Historical Status of New Art Styled Architectures in Harbin, Journal of Architecture, Nov. 1996.

[5] Liu Daping \& Wang Yan. New Art Styled Architectures in Harbin Harbin Institute of Technology Press, Oct. 2016 